\title{
Ecchordosis physaliphora - a case report and a review of notochord-derived lesions
}

\section{Ecchordosis physaliphora - opis przypadku i omówienie patologicznych pochodnych struny grzbietowej}

Dariusz Adamek', Michalina Malec², Natalia Grabska², Anna Krygowska-Wajs³, Krystyna Gałąka'

'Department of Pathology, Jagiellonian University Medical College, Krakow

2Student of Medical Faculty, Jagiellonian University Medical College, Krakow

${ }^{3}$ Department of Neurology, Jagiellonian University Medical College, Krakow

Neurologia i Neurochirurgia Polska 2011; 45, 2: 169-173

\begin{abstract}
Some notochord cells remain along the axis of the vertebral column after embryogenesis. These 'notochordal remnants' have some similarities, but their biological behaviour varies considerably. They can give rise to benign lesions such as ecchordosis physaliphora (EP) and 'benign notochordal cell tumour' (BNCT), or aggressive ones like chordoma.

We review the problems of the differential diagnosis of notochordal remnants apropos of a case of the incidental autopsy finding of EP in a 78-year-old man, who died due to heart infarction. The 6-mm asymptomatic gelatinous lesion was fixed to the basilar artery on its ventral aspect.

Small EPs can be easily overlooked in autopsy. Ecchordosis physaliphora and intradural chordoma share some similarities that may be misleading and may even result in the wrong diagnosis and therapy. The recently reported new entity BNCT poses a similar problem. We review the literature illustrating the most important features of notochord-derived lesions and discuss the relationships between these lesions with regard to molecular genetics.
\end{abstract}

Key words: chordoma, notochord, basilar artery, nucleus pulposus, autopsy.

\section{Streszczenie}

Podczas formowania się jąder miażdżystych na pozostałościach komórek struny grzbietowej rozwijają się zmiany podobne do siebie, mające jednak różny przebieg kliniczny. Niektóre $\mathrm{z}$ nich, takie jak ecchordosis physaliphora (EP) i notochordal benign cell tumour (NBCT), mają charakter łagodny, inne (np. struniak) - agresywny. Celem pracy jest przegląd najważniejszych cech zmian wywodzących się ze struny grzbietowej i ich diagnostyka różnicowa na podstawie przypadku EP stwierdzonego podczas autopsji mózgu 78-letniego mężczyzny zmarłego na atak serca. Galaretowaty guz o największym wymiarze $6 \mathrm{~mm}$, przytwierdzony do brzusznej części tętnicy podstawnej nie dawał żadnych objawów.

Ecchordosis physaliphora to zazwyczaj mały, bezobjawowy guzek, łatwy do przeoczenia podczas autopsji. Struniak i EP wywodzą się z tych samych komórek, lecz ze względu na podobieństwa mogą być ze sobą mylone, co skutkuje niewłaściwym rozpoznaniem i ewentualnym leczeniem. Podobny problem występuje w przypadku NBCT. W pracy poruszono również kwestię ich wzajemnego związku na podstawie badań genetycznych.

Słowa kluczowe: struniak, struna grzbietowa, tętnica podstawna, jądro miażdżyste, autopsja.

Correspondence address: Natalia Grabska, Katedra Patomorfologii, ul. Grzegórzecka 16, 31-531 Kraków, phone: +48 1242115 64, +48124247263, fax +48124119725, e-mail:nath87@wp.pl

Received: 18.10.2010; accepted: 14.12.2010 


\section{Introduction}

The notochord develops in humans during the third week of embryonic life and persists in adults as the nucleus pulposus of the intervertebral discs. During formation of the nucleus pulposus, some cells of the notochord remain along the axis of the vertebral column. They can create clinically important lesions ranging from ecchordosis physaliphora, through benign notochordal cell tumours (BNCTs), to a rare type of tumour called chordoma. These 'notochordal derivatives' have a lot of pathological similarities, but their biological behaviour varies considerably. The problem of their differential diagnosis affects the modalities of clinical treatment.

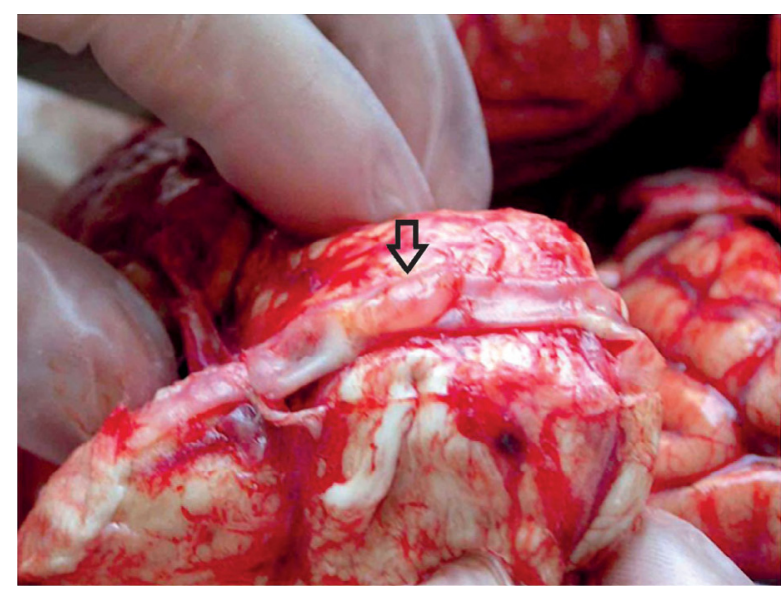

Fig. 1. Macroscopic in situ picture of ecchordosis physaliphora. Small jelly-like tubercle attached to basilar artery (arrow)

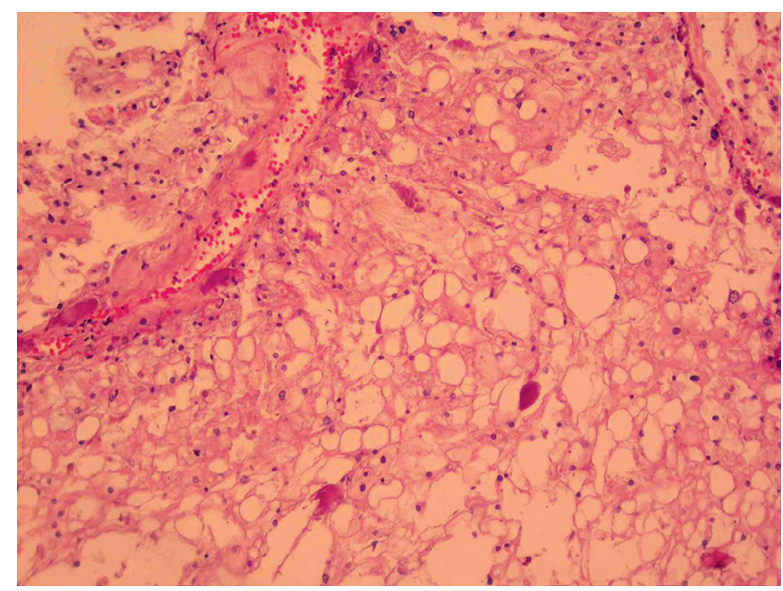

Fig. 2. Microscopic picture of ecchordosis physaliphora shows a tissue composed of cells with ample, sometimes strongly vacuolated cytoplasm without distinct borders, with small, bland nuclei, focally interspersed within myxoid matrix (haematoxylin-eosin, HE)

\section{Case report}

During the autopsy of a 78-year-old man, who died due to heart infarction, a lesion $6 \times 4 \times 3 \mathrm{~mm}$, fixed to the basal artery on its ventral site, without infiltration of the artery, was found. It was well circumscribed, glossy, with gelatinous consistency (Fig. 1).

Microscopically, the lesion was formed by loosely packed cells with bland nuclei and ample vacuolated ('physaliphorous') cytoplasm dispersed within a myxoid background (Figs. 2 and 3). Immunohistochemical staining showed positivity for S-100, neuron-specific enolase (NSE), and epithelial membrane antigen (EMA) (Fig. 4). No mitoses were visible and immune labelling for topoisomerase-2-alpha (proliferative anti-

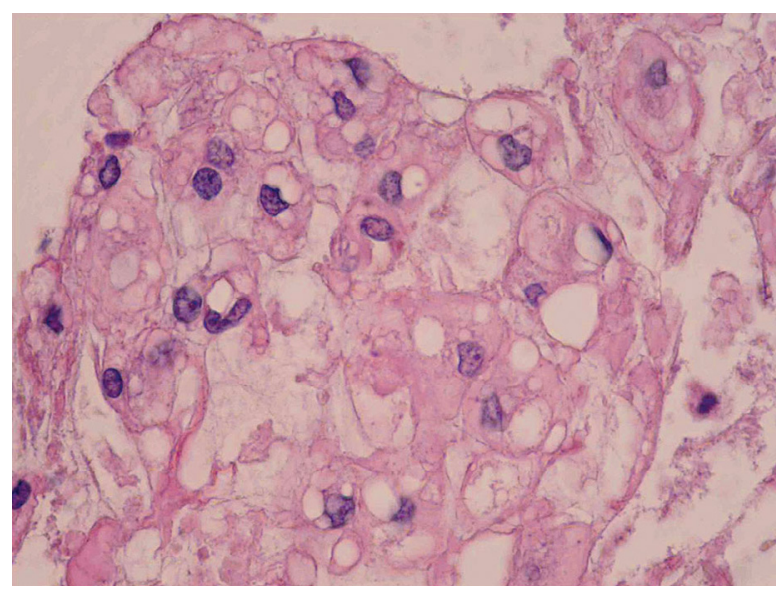

Fig. 3. High power picture of ecchordosis physaliphora. The most characteristic cells, called physaliphorous, have numerous, small intracytoplasmic vacuoles (HE)

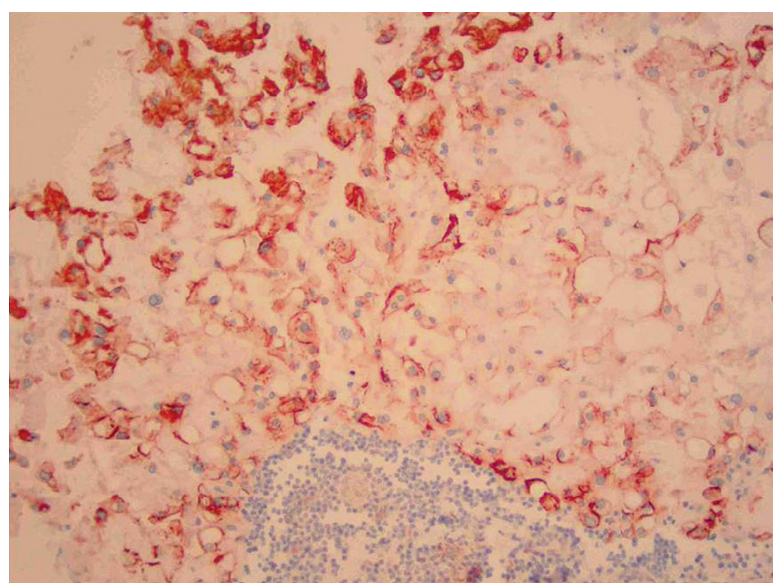

Fig. 4. Immunohistochemistry with antibody against EMA shows strong positivity. Noteworthy are the clusters of lymphocytes that can be seen in the lower part of the picture, which may suggest a form of immune response to the lesion 
gen) was negative, which suggests a benign character of the lesion. As a result, ecchordosis physaliphora was diagnosed. There was no evidence of clinical manifestation.

\section{Discussion}

Ecchordosis physaliphora is usually a small lesion, from a few millimetres to $2 \mathrm{~cm}$ in its maximum diameter (see [1] for review). The most typical localization of ecchordosis physaliphora is the prepontine cistern along the clivus and dorsum sellae in the extradural, intradural or subarachnoid space [2]. It is observed in $0.5-2 \%$ of autopsies (possibly reflecting the level of thoroughness of necropsy) [3]. The localization of ecchordosis physaliphora on the clivus is probably due to the fact that it is the place where the sigmoid curve of the chorda dorsalis reaches the osseous surface [4]. The magnetic resonance images (MRI) of ecchordosis physaliphora are very characteristic. The lesion is hypointense on T1-weighted scans, hyperintense on T2weighted scans, and there is no enhancement after gadolinium administration [4]. Computed tomography (CT) is not very useful because of the small size of the lesion and possible artefacts in the posterior fossa. However, Toda et al. claim that a stalk-like structure projecting from the clivus is the hallmark of ecchordosis physaliphora on CT scans [1].

As in our case, typically ecchordosis physaliphora is asymptomatic. According to our best knowledge, only 9 symptomatic patients have been reported so far [4]. The symptoms include: headache, sudden sensorineural hearing loss, diplopia, hemiparesis, hemihypoesthesia, and cerebrospinal fluid fistula; it may finally manifest with fatal pontine, subarachnoid or intratumoural haemorrhage [2].

Its histopathological picture is characteristic and resembles that of notochord. It consists of multivacuolated cells with regular nuclei. These quite characteristic cells are frequently referred to as physaliphorous. The vacuoles can cluster, forming bigger cysts. On the peripheral region of the lesion, oval, round or radial cells, sometimes with irregular, multilobular nuclei, might be found. The vacuoles are often filled with granular or fibrillar material which is reddish in PAS and Alcian blue staining and metachromatic in toluidine blue staining. In immunohistochemistry ecchordosis physaliphora is positive for cytokeratins, EMA, NSE and S-100 protein and focally for vimentin [5].
This description is very similar to an extremely rare type of chordoma which is localized extraosseously and intradurally [2]. Both lesions have similar anatomical location (i.e. clivus) and clinical behaviour and originate from the same embryological remnant. The histological picture is also comparable. The difference is that the chordoma cells aggregate in nests or cords. They have almost the same signal intensity on MRI, but intradural chordoma usually shows considerable contrast enhancement. Unlike classical chordoma, in most cases these two lesions do not demonstrate extensive bone destruction [2]. As already mentioned, the indicator of ecchordosis physaliphora may be a thin stalk seen on CT scans [2]. Nonetheless, the differential diagnosis based on the radiological scans and even histopathology is difficult. Immunohistochemistry is also very similar except that the Ki-67 index is usually higher in chordoma $[2,4]$. As previously indicated, both lesions have similar biological behaviour and clinical symptoms. After surgical treatment they have no or low risk of recurrence though when left untreated they may be lethal [4]. It is important to note that their first symptom may be intratumoural, subarachnoid or pontine haemorrhage, which may be fatal [2]. Thus, the treatment might be the same in both cases. Ecchordosis physaliphora is usually left untreated until the symptoms occur. Complete surgical resection is considered in the case of intradural chordo$\mathrm{ma}$, as in the classical one [2]. Because of these similarities, some authors believe that ecchordosis physaliphora may turn into an intradural chordoma expressing a higher level of proliferation activity [6].

Another issue is the differentiation between the 'classical' chordoma and another notochordal derivative which is so-called benign notochordal cell tumour (BNCT).

Some authors report that BNCT can be identified in 20\% of carefully performed autopsies [7]. This lesion is a benign aggregation of cells, which originate from embryonic notochord. It is located in the axial skeleton. Probably, it is a potential precursor of chordoma [7]. Both lesions have a predilection for the same anatomical location. They occur in the sacro-coccygeal region in approximately $50 \%$ of cases and the second most common location is the base of the skull. BNCTs are asymptomatic for a long time, but rarely the first symptom can be pain. The diagnostics based on radiological features is very important. The $\mathrm{CT}$ scan shows a sclerotic lesion inside the vertebral body or another intraosseous place, in contrast to chordoma, which does not produce a sclerotic reaction of bone and there is no bone destruction 
seen on the scans. MR T1-weighted images mostly reveal homogeneous low signal intensity. MR T2-weighted images reveal intermediate to bright signal intensity. There is no contrast enhancement.

Its histological picture shows adipocyte-like vacuolated chordoid cells intermingled with less vacuolated eosinophilic cells of various degrees. It is not lobulated, and there is no myxoid background. The affected bone trabeculae are sclerotic because of appositional or reactive new bone formation. These characteristics were identical in the majority of reported cases so far [7].

Immunostaining shows a positive reaction for cytokeratin, EMA, S-100 protein and vimentin.

The biological behaviour of BNCT implies that the lesion does not demand surgical treatment unless it undergoes malignant transformation. The latest studies indicate that it can turn into a chordoma but this is a very rare situation.

As already mentioned, chordoma, which is a rare malignant tumour of the axial skeleton in the region of the embryonic notochord, is located in the same places as BNCT. The radiological findings differ in some aspects. Firstly, lesions are destructive, osteolytic, and associated with a soft tissue mass infiltrating adjacent tissue on CT scans. MR images show contrast enhancement. It is important that despite the fact that chordoma is a locally malignant tumour, it can give metastases in $10-40 \%$ of cases [8], mostly to the liver, regional lymph nodes, lungs, bones and skin. The symptoms depend on the location. Intracranial lesions cause headaches and often unilateral cranial nerve palsies, particularly diplopia. Chordomas located in the spine usually produce pain, and lesions in the sacro-coccygeal region cause sphincter disturbances and neurological symptoms from pressure upon regional nerve roots. From the histological point of view, there are differences between chordoma and the derivatives of notochord. Firstly, this tumour is lobulated, often haemorrhagic and destroys the bone. Regions of calcification can be found. Microscopic images show cells aggregating in nests or cords. The cytological appearance varies from non-vacuolated, eosinophilic cells to multivacuolated (physaliphorous) ones. The myxoid matrix, rich in mucopolysaccharides, makes up the background of the lesion. Immunostaining is positive for cytokeratins except CK18, which is important because the lesions reviewed above are positive for this keratin. Besides EMA, focally S-100 and vimentin are also positive. Because of the similarities, differential diagnosis based on histopathology and immunostaining is difficult.
Thus, it seems that the radiological images better differentiate these lesions [7].

It is thought that chordoma evolves from BNCT. As already mentioned, the latter lesion is prevalent, unlike the former; therefore one may infer that the transformation is a very rare event [8]. The signals that initiate chordoma formation are unknown. However, it is interesting that an amplification of 7q36 is the most common alteration in human chordomas that has been reported and occurs in $69 \%$ of these types of tumours. The region of chromosome 7 implicated in chordoma formation contains the gene $\operatorname{Shh}[1,9]$. This gene is responsible for creation of many other neoplasms, e.g. medulloblastoma. The product of the gene also participates in the formation of the embryonic notochord and spinal cord.

In conclusion, it is important to know the characteristics of lesions which originate from the same structure of the embryonic notochord because some subtle differences influence the choice of the best treatment and the prognosis. In the case of ecchordosis physaliphora and intradural chordoma, it is important that they are mainly asymptomatic, but the first symptom may be intracranial haemorrhage. Also, intradural chordoma has non-invasive character, unlike the classic one, which is important for the therapeutic alternatives. In turn, BNCT and classic chordoma are often misdiagnosed. It is important, therefore, to know the radiological features. It is worth investigating the question of transformation of $\mathrm{BNCT}$ to chordoma. It could give the possibility of early medical intervention, which ensures better prognosis.

\section{Disclosure}

Authors report no conflict of interest.

\section{References}

1. Toda H., Kondo A., Iwasaki K. Neuroradiological characteristics of ecchordosis physaliphora. Case report and review of the literature. J Neurosurg 1998; 89: 830-834.

2. Alkan Ö., Yildirim T., Kozilkilic O., et al. A Case of ecchordosis physaliphora presenting with an intratumoral hemorrhage. Turk Neurosurg 2009; 19: 293-296.

3. Fracasso T., Brinkmann B., Paulus W. Sudden death due to subarachnoid bleeding from ecchordosis physaliphora. Int J Legal Med 2008; 122: 225-227.

4. Ciarpaglini R., Pasquini E., Mazzatenta D., et al. Intradural clival chordoma and ecchordosis physaliphora: a challenging differential diagnosis: case report. Neurosurgery 2009; 64: 387-388. 
5. Sarasa J.L., Fortes J. Ecchordosis physaliphora: an immunohistochemical study of two cases. Histopathology 1991; 18: 273-275.

6. Katayama Y., Tsubokawa T., Hirasawa T., et al. Intradural extraosseous chordoma in the foramen magnum region. $J$ Neurosurg 1991; 75: 976-979.

7. Yamaguchi T., Iwata J., Sugihara S., et al. Distinguishing benign notochordal cell tumors from vertebral chordoma. Skeletal Radiol 2008; 37: 291-299.

8. Kłosiński P., Lisiecki J., Goździewicz J., et al. Chordoma leczenie i rokowanie. Wspótcz Onkol 2003; 2: 107-114.

9. Choi K.S., Cohn M.J., Harfe B.D. Identification of nucleus pulposus precursor cells and notochordal remnants in the mouse: implications for disk degeneration and chordoma formation. Dev Dyn 2008; 237: 3953-3958. 